\title{
PENGARUH DISIPLIN KERJA TERHADAP KINERJA PEGAWAI PADA PT WOM FINANCE KEBUMEN
}

\author{
Blandina Hendrawardani ${ }^{1}$ dan Sukamto ${ }^{2}$ \\ Politeknik Dharma Patria Kebumen \\ blandina.hendra@gmail.com; jokosukamto83@gmail.com
}

\begin{abstract}
ABSTRAK
Perusahaan dalam usahanya mencapai tujuan organisasinya memerlukan sumber daya manusia yang berkinerja tinggi. Kecanggihan teknoloogi yang dimiliki oleh perusahaan tidaklah ada artinya apabila tidak didukung oleh sumber daya manusia yang memadai. Penelitian ini bertujuan untuk mengetahui pengaruh antara disiplin kerja terhadap kinerja pegawai pada PT WOM Finance Kebumen. Metode penelitian yang digunakan adalah metode kuantitatif deskriptif. Metode analisis yang digunakan adalah korelasi Rank Spearman dan koefisien determinasi.Hasil penelitian menunjukkan bahwa disiplin pegawai dan kinerja pegawai pada PT WOM Finance Kebumen berada pada kategori baik pada angka $80,63 \%$ dan $80 \%$. Hubungan antara variabel disiplin kerja dengan kinerja pegawai sebesar 0,833 pada taraf signifikansi 5\% sehingga derajat hubungannya sangat kuat pada arah yang positif. Koefisien determinasinya menunjukkan angka 0,682 yang berarti variabel kinerja pegawai dijelaskan oleh variabel disiplin kerja sebesar 68,2\% dan selebihnya sebesar $21,8 \%$ dijelaskan oleh faktor lain diluar penelitian ini.
\end{abstract}

Kata Kunci: Displin, Kinerja dan Karyawan

\begin{abstract}
Companies in achieving organizational goals requires human resources with high performance. Sophistication teknoloogi owned by the company does not mean anything if they are not supported by adequate human resources. This study aimed to determine the effect of labor discipline on the performance of employees at PT WOM Finance Kebumen. The method used is descriptive quantitative method. The analytical method used is the Spearman rank correlation and coefficient of determination. The results showed that employee discipline and performance of employees at PT WOM Finance Kebumen are in either category in number 80,63\% and 80\%. The relationship between the variables of labor discipline with the performance of employees amounted to 0,833 at the 5\% significance level that the degree is very strong relationship in a positive direction. The coefficient of determination showed 0.682 which means that the variable is explained by the variable performance of employees working discipline by $68.2 \%$ and the remaining $21.8 \%$ is explained by other factors beyond the study.
\end{abstract}

Keywords: Discipline, Performance, and Employee.

\section{A. PENDAHULUAN}

Masalah sumber daya manusia terus menjadi sorotan bagi organisasi untuk tetap dapat bertahan di era globalisasi. Sumber daya manusia mempunyai peran utama dalam setiap kegiatan organisasi. Walaupun didukung dengan sarana dan prasarana serta sumber dana yang berlebihan, tetapi tanpa dukungan sumber daya manusia yang andal, kegiatan organisasi tidak akan terselesaikan dengan baik.

Pengembangan sumber daya manusia mengandung tugas untuk mendayagunakan sumber daya manusia yang dimiliki oleh suatu lembaga. Hal ini menunjukkan bahwa sumber daya manusia merupakan kunci pokok yang harus diperhatikan dengan segala kebutuhannya. Sebagai kunci pokok, sumber daya manusia akan menentukan keberhasilan pelaksanaan kegiatan organisasi. Tuntutan organisasi untuk memperoleh, mengembangkan dan mempertahankan sumber daya manusia yang berkualitas semakin mendesak sesuai dengan dinamika lingkungan yang selalu 
berubah. Perubahan perlu mendapat dukungan pimpinan puncak sebagai langkah pertama yang penting untuk dilakukan bukan hanya sekedar lip service saja.

Organisasi merupakan sarana kegiatan orang-orang dalam usaha mencapai tujuan bersama. Dalam wadah kegiatan ini, setiap orang atau pegawai harus memiliki kemampuan yang tinggi dalam melaksanakan tugas, wewenang dan tanggung jawabnya masing-masing sesuai dengan jabatannya. Pengembangan sumber daya manusia mengandung tugas untuk mendayagunakan sumber daya manusia yang dimiliki oleh suatu lembaga secara optimal, sehingga sumber daya manusia dapat bekerja secara maksimal untuk bersama-sama mencapai tujuan sesuai dengan visi dan misi organisasi.

Dalam hampir setiap organisasi, pegawai dalam melakukan tugasnya atau pekerjaannya sering tidak sesuai dengan yang diharapkan. Mereka sering melakukan kesalahan yang tidak seharusnya terjadi misalnya sering tidak masuk kerja, tidak sungguh-sungguh mematuhi peraturan jam kerja. Hal ini akan berakibat tidak baik bagi organisasi, karena pekerjaan menjadi sering tidak dapat terselesaikan sesuai waktu yang ditentukan, banyak waktu tidak terpakai dengan baik. Mereka beranggapan bekerja pada sebuah perusahaan / instansi itu tidak perlu bekerja maksimal, karena gaji sudah ditetapkan jumlahnya, tunjangan sudah diberikan.

Selain itu fenomena masih adanya pegawai yang tidak bekerja pada saat jam kerja atau memanfaatkan waktu kerja untuk melakukan hal-hal lain di luar pekerjaannya. Hal ini berakibat pada rendahnya kinerja pegawai, karena perhatiannya terbagi dengan aktifitasnya di luar dari kewajibannya, sehingga pegawai tersebut tidak secara total memberikan pengabdian diri pada organisasi.

Pada penelitian ini penulis tertarik untuk menganalisa upaya yang dilakukan dalam peningkatan kinerja pegawai pada perusahaan melalui disiplin kerja. Pegawai di PT WOM Finance terbagi menjadi dua bagian yaitu pegawai yang bertugas di kantor dan pegawai lapangan. Di dalam melaksanakan tugasnya tersebut tentu harus memiliki sumber daya manusia yang berkinerja tinggi sehingga diharapkan produktifitas juga tinggi.

\section{B. METODOLOGI PENELITIAN}

\section{Metode Penelitian}

Metode penelitian ini menggunakan metode kuantitatif dengan analisis deskriptif. Menurut Sugiyono (2009: 7) menyatakan bahwa: metode ini disebut metode kuantitatif karena menggunakan data statistik.

Selanjutnya menurut Muhktar dan Erna Widodo (2001: 15) mengungkapkan bahwa metode penelitian deskriptif adalah suatu metode yang digunakan untuk menemukan pengetahuan seluasluasnya terhadap obyek penelitian pada suatu saat tertentu.

Penelitian ini bertujuan menggambarkan keadaan atau fenomena yang terjadi di lapangan. Penelitian ini dimaksudkan untuk menguji hipotesis yang telah dilakukan dengan cara mencari besarnya variabel bebas terhadap variabel terikat. Melalui metode kuantitatif dengan analisis deskriptif ini diharapkan dapat diketahui sejauh mana pengaruh disiplin kerja terhadap kinerja pegawai di PT WOM Finance Kebumen.

\section{Populasi dan Sampel}

\section{Populasi Penelitian}


Populasi adalah keseluruhan subyek penelitian. Populasi dalam penelitian ini adalah pegawai lapangan di PT WOM Finance Kebumen sejumlah 20 orang.

\section{Sampel Penelitian}

Sampel dalam penelitian ini tidak digunakan karena jumlah populasi di bawah 100 orang sehingga semua populasi dijadikan subyek penelitian.

\section{Definisi Operasional Variabel}

Sub bab ini akan menjelaskan secara ringkas menganai operasionalisasi dari variabelvariabel yang digunakan dalam model penelitian ini. Definisi operasional variabel yang akan digunakan pada penelitian ini dapat dilihat pada Tabel 3.1. di bawah ini.

\begin{tabular}{|c|c|c|c|}
\hline Variabel & Definisi Operasional Variabel & Indikator Variabel & $\begin{array}{l}\text { Skala } \\
\text { Pengukuran }\end{array}$ \\
\hline $\begin{array}{l}\text { Disiplin } \\
\text { Kerja (X) }\end{array}$ & $\begin{array}{l}\text { Sikap atau tingkah laku yang } \\
\text { menunjukkan kesetiaan dan } \\
\text { ketaatan seseorang atau } \\
\text { sekelompok orang terhadap } \\
\text { peraturan yang telah ditetapkan } \\
\text { oleh instansi atau organisasinya } \\
\text { baik yang tertulis maupun tidak } \\
\text { tertulis sehingga diharapkan } \\
\text { pekerjaan yang dilakukan } \\
\text { efektif dan efesien. }\end{array}$ & $\begin{array}{l}\text { Ketepatan Waktu } \\
\text { Menggunakan Peralatan } \\
\text { Kantor dengan Baik } \\
\text { Tanggung jawab yang } \\
\text { tinggi } \\
\text { Ketaatan terhadap aturan } \\
\text { Kantor }\end{array}$ & $\begin{array}{l}\text { Likert } \\
\text { Pada skala } 1 \\
-5\end{array}$ \\
\hline $\begin{array}{l}\text { Kinerja } \\
\text { Pegawai } \\
\text { (Y) }\end{array}$ & $\begin{array}{l}\text { hasilseseorangsecarakeseluruha } \\
\text { n selama } \\
\text { periodetertentudidalammelaksan } \\
\text { akantugas,sepertistandarhasilker } \\
\text { ja,target atau sasaran } \\
\text { ataukriteria } \\
\text { yangtelahditentukanterlebihdah } \\
\text { uludantelahdisepakati bersama. }\end{array}$ & $\begin{array}{l}\text { Kualitas Kerja } \\
\text { Kuantitas Kerja } \\
\text { Kreativitas } \\
\text { Kerja sama }\end{array}$ & $\begin{array}{l}\text { Likert } \\
\text { Pada skala } 1 \\
-5\end{array}$ \\
\hline
\end{tabular}

\section{Metode Pengumpulan Data}

Penggunaan teknik pengumpulan data peneliti memerlukan teknik sebagai alat bantu agar pengerjaan pengumpulan data menjadi lebih mudah. Teknik pengumpulan data yang digunakan dalam penelitian ini menggunakan teknik Angket / Kuisoner. Pada penelitian ini, kuesioner disebar kepada seluruh pegawai yang bertugas di lapangan. Kuesioner penelitian disusun disusun menurut indikator-indikator penelitian yang diperoleh dari pengembangan hasil kajian pustaka. Pengukuran kuesioner menggunakan skala data ordinal dan skala pengukurannya menggunakan Skala Likert.

Sugiyono (2012:73) menjelaskan: Skala Likert digunakan untuk mengukur sikap, pendapat dan persepsi seseorang atau sekelompok orang tentang fenomena sosial. Jawaban setiap item instrumen yang menggunakan Skala Likert mempunyai gradasi dari sangat positif sampai sangat negatif, yang berupa kata-kata antara lain :

1. Sangat setuju

2. Setuju

3. Kurang setuju

4. Tidak setuju

5. Sangat tidak setuju

Untuk keperluan analisis kuantitatif, maka jawaban itu diberi skor sebagai berikut : 
1. Sangat setuju diberi skor 5

2. Setuju diberi skor 4

3. Kurang setuju diberi skor 3

4. Tidak setuju diberi skor 2

5. Sangat tidak setuju diberi skor 1

\section{Uji Validitas dan Reliablitas}

\section{Uji Validitas}

Uji validitas berguna untuk mengetahui apakah alat ukur tersebut valid, valid artinya ketepatan dan kecermatan mengukur atau alat ukur tersebut tepat untuk mengukur sebuah variabel yang akan diukur.Uji validitas dilakukan pada setiap butir pertanyaan, dan hasilnya dapat dilihat melalui hasil $r$-hitung yang dibandingkan dengan $r$-tabel, dimana $r$-tabel dapat diperoleh melalui $\mathrm{df}($ degree of freedom $)=\mathrm{n}-2($ signifikan $5 \%, \mathrm{n}=$ jumlah sampel). Jika $\mathrm{r}-$ tabel $<$ r-hitung maka valid

Jika r-tabel > r-hitung maka tidak valid. Berdasarkan jumlah $\mathrm{N}$ yaitu 20 reponden, maka diketahui jumlah $r$ tabel sebesar Item yang punya $r$ hitung $<0,444$ akan disingkirkan akibat mereka tidak melakukan pengukuran secara sama dengan yang dimaksud oleh skor total skala dan lebih jauh lagi, tidak memiliki kontribusi dengan pengukuran seseorang jika bukan malah mengacaukan.

\section{Uji Reliabilitas}

Reliabilitas instrumen adalah tingkat konsistensi hasil yang dicapaioleh sebuah alat ukur, meskipun dipakai secara berulang-ulang pada subjek yang sama atau berbeda. Dengan demikian suatu instrument dikatakan reliabel bila mampu mengukur sesuatu dengan hasil yang konsisten (ajeg). (Modul Metodologi Penelitian: 2013).

Uji realibilitas untuk melihat alat ukur, dalam hal ini daftar pertanyaan yang digunakan konsisten atau tidak. Uji reliabilitas dilakukan pada butir-butir pertanyaan yang telah memiliki validitas. Uji instrumen dapat dikatakan reliabel apabila $\alpha$ lebih besar dari 0,6. (Nunnally dalam Zethmal, Berry dan Parasuraman, 1996).

\section{Teknik Analisis Data}

Analisis data adalah dalam rangka melakukan uji hipotesis. Teknik analisis yang digunakan dalam penelitian ini adalah:

\section{Teknik Analisis Statistik Data Deskriptif}

Yaitu pemaparan data-data penelitian meliputi disiplin dan kinerja pegawai dalam bentuk tabel-tabel dan penjelasannya. Untuk mengetahui pengkategorian kondisi setiap variabel, digunakan tabel dan rumus sebagai berikut:

Tabel 3.2. Pengkategorian skor distribusi frekuensi

\begin{tabular}{|c|c|}
\hline $0-20$ & Sangat Tidak Baik \\
\hline $21-40$ & Tidak Baik \\
\hline $41-60$ & Cukup Baik \\
\hline $61-80$ & Baik \\
\hline $81-100$ & Sangat Baik \\
\hline
\end{tabular}

Sumber : Data Diolah

Skor maksimal/ideal :

skor nilai riilx 100

skor nilai ideal 


\section{Penyesuaian Hipotesis}

1. Teknik Analisis Korelasi Rank Spearman

Analisis korelasi berusaha mengukur eratnya hubungan antara dua variabel independen (X) dengan vaiabel dependen $(\mathrm{Y})$ dengan menggunakan suatu bilangan yang disebut koefisien korelasi (r).

Rumus korelasi Rank Spearman:

$$
r=1-\left(\frac{6 \sum b_{i}^{2}}{N\left(N^{2}-1\right)}\right)
$$

Nilai korelasi berada antara $-1 \leq \mathrm{r} \leq 1$

$-1=$ korelasi negative yang sempurna

$1=$ korelasi positif yang sempurna

$0=$ tidak ada korelasi antara $\mathrm{x}$ dan $\mathrm{y}$

Jika $\mathrm{r}$ semakin mendekati angka -1 atau 1, maka antara dua variabel mempunyai hubungan yang kuat atau erat. Sedangkan jika $r$ lebih mendekati ke angka 0 , maka antara dua variabel mempunyai hubungan yang tidak kuat atau tidak erat.

Tabel 3.3. Interpretasi koefisien korelasi

\begin{tabular}{|l|c|l|}
\hline$O$ & $:$ & Tidak ada korelasi \\
\hline $0,00-0,25$ & $:$ & Korelasi sangat lemah \\
\hline $0,25-0,50$ & $:$ & Korelasi cukup \\
\hline $0,50-0,75$ & $:$ & Korelasi kuat \\
\hline $0,75-0,99$ & $:$ & Korelasi sangat kuat \\
\hline 1 & $:$ & Korelasi sempurna \\
\hline
\end{tabular}

Sumber : Jhonatan Sarwono, 2009, Yogyakarta.

\section{Uji Determinasi}

Berkaitan dengan pembuktian hipotesis, digunakan uji koefisien determinasi $\left(\mathrm{r}^{2}\right)$. Koefisien determinasi adalah untuk menentukan seberapa besar variasi variabel dependen $(\mathrm{Y})$ yang dapat dijelaskan oleh variabel independen (X). koefisien determinasi adalah $0 \leq \mathrm{r}^{2} \leq 1$. Jika $\mathrm{r}^{2}=0$ maka garis regresi sangat tidak dapat mencocokkan atau sangat tidak tepat dalam meramalkan nilai Y. Jika $\mathrm{r}^{2}=1$ maka garis regresi sangat cocok atau sangat tepat untuk meramalkan nilai Y. Dalam realita nilai $\mathrm{r}^{2}$ tidak mungkin 1 atau $100 \%$ tetapi selalu di bawah 1 atau $100 \%$.

\section{HASIL DAN PEMBAHASAN}

\section{Analisis Hasil Penelitian}

A. Analisis Uji Instrumen

1. Uji Validitas dan Reliabilitas Kuesioner

Uji Validitas dan Reliabilitas Kuesioner adalah digunakan untuk mengetahui valid-reliabel tidaknya suatu daftar pertanyaan sebelum daftar pertanyaan tersebut disebarkan ke responden. Dengan pengujian ini, kuesioner disebarkan kepada 20 responden (lihat lampiran data Uji Validitas dan Reliabilitas Kuesioner). Setelah data terkumpul kemudian data diolah dengan program SPSS.

a. Uji Validitas

Uji validitas kuisioner dalam penelitian ini menggunakan uji korelasi product moment Pearson. Melalui uji ini masing-masing item dalam variabel dapat diidentifikasi validitasnya sebagai berikut (selengkapnya lihat lampiran hasil uji validitas).

1) Disiplin Kerja ( Variabel $X$ ) 
Berikut ini disajikan tabel dari data hasil uji validitas kuesioner pada variabel Disiplin Kerja:

Tabel 4.1. Hasil Uji Validitas Variabel X

\begin{tabular}{|c|c|c|c|}
\hline $\begin{array}{c}\text { Item } \\
\text { No. }\end{array}$ & r hitung & r table & Status \\
\hline 1. & 0.625 & 0.444 & Valid \\
\hline 2. & 0.576 & 0.444 & Valid \\
\hline 3. & 0.614 & 0.444 & Valid \\
\hline 4. & 0.580 & 0.444 & Valid \\
\hline 5. & 0.591 & 0.444 & Valid \\
\hline 6. & 0.659 & 0.444 & Valid \\
\hline 7. & 0.599 & 0.444 & Valid \\
\hline 8. & 0.637 & 0.444 & \\
\hline
\end{tabular}

Sumber: hasil olah data validitas kuisioner

Berdasarkan hasil olah data di atas, diketahuhi bahwa semua item pertanyaan dalam varibel disiplin kerja valid.

2) Kinerja Pegawai ( Variabel Y )

Berikut ini disajikan tabel dari data hasil uji validitas kuesioner pada variabel Kinerja Pegawai:

Tabel 4.2. Hasil Uji Validitas Variabel Y

\begin{tabular}{|c|c|c|c|}
\hline $\begin{array}{c}\text { Item } \\
\text { No. }\end{array}$ & r hitung & r table & Status \\
\hline 9. & 0.637 & 0.444 & Valid \\
\hline 10. & 0.597 & 0.444 & Valid \\
\hline 11. & 0.597 & 0.444 & Valid \\
\hline 12. & 0.637 & 0.444 & Valid \\
\hline 13. & 0.742 & 0.444 & Valid \\
\hline 14. & 0.729 & 0.444 & Valid \\
\hline 15. & 0.750 & 0.444 & Valid \\
\hline 16. & 0.742 & 0.444 & Valid \\
\hline 17. & 0710 & 0.444 & \\
\hline
\end{tabular}

Sumber: hasil olah data validitas kuisioner

Berdasarkan hasil olah data di atas, diketahuhi bahwa semua item pertanyaan valid dalam varibel Kinerja Pegawai.

\section{Uji Reliablitas}

Suatu instrumen dapat dikatan reliabel apabila $\alpha>0,6$. (Nunnally dalam Zeithaml, Berry dan Parasuraman, 1996). Item kuesioner yang diolah adalah item yang diketahui valid. Berdasarkan hasil olah data dengan program SPSS menunjukkan bahwa koefisien reliabilitasnya sebagai berikut (selengkapnya lihat lampiran hasil uji reliabilitas) :

Tabel 4.3. Hasil Uji Reliabilitas dengan cronbach's alpha 


\begin{tabular}{|c|c|c|}
\hline Jumlah Item Pertanyaan & Alpha ( $\boldsymbol{\alpha})$ & Status \\
\hline 17 & 0,631 & Reliabel \\
\hline
\end{tabular}

Sumber: hasil olah data reliabilitas kuisioner

B. Analisis Deskriptif

Keseluruhan responden dalam penelitian ini berjumlah 20 orang. Adapun analisis deskriptif untuk setiap indikator dari variabel penelitian ini setelah data diolah menggunakan SPSS diketahui sebagai berikut:

1. Variabel Disiplin Kerja (X)

Data variabel Disiplin Kerja (X) diperoleh melalui data primer berupa angket dengan 4 indikator dan ... butir pernyataan. Berdasarkan data variabel Disiplin Kerja yang diolah menggunakan bantuan program SPSS Statistics diperoleh sebagai berikut:

a. Indikator Ketepatan Waktu

Indikator ini terdiri dari dua item pertanyaan yang distribusi jawabannya tertuang dalam tabel 4.4. dan tabel 4.5. di bawah ini.

Tabel 4.4. Item Pertanyaan No. 1

\begin{tabular}{|ll|l|l|l|l|}
\hline & & & & Cumulative \\
& & Frequency & Percent & Valid Percent & Percent \\
\hline Valid & 4 & 11 & 55.0 & 55.0 & 55.0 \\
& 5 & 9 & 45.0 & 45.0 & 100.0 \\
& Total & 20 & 100.0 & 100.0 & \\
\hline
\end{tabular}

Sumber: Distribusi Frekuensi Data

Berdasarkan Tabel 4.4. diketahui dari item pertanyaan kuesioner no 1 yaitu: Pegawai datang ke kantor tepat waktu. Dari 20 responden, sebanyak $11(55,0 \%)$ orang menjawab setuju dan $9(45,0 \%)$ orang menjawab sangat setuju. Hal ini menunjukkan bahwa pegawai datang ke kantor telah tepat waktu.

Tabel 4.5. Item Pertanyaan No. 2

\begin{tabular}{|ll|l|l|l|l|}
\hline & & & & $\begin{array}{l}\text { Cumulative } \\
\text { Percent }\end{array}$ \\
\hline Valid & 3 & 5 & Percent & Valid Percent & 25.0 \\
& 4 & 15 & 25.0 & 25.0 & 100.0 \\
& Total & 20 & 75.0 & 75.0 & \\
\hline
\end{tabular}

Sumber: Distribusi Frekuensi Data

Berdasarkan Tabel 4.5. diketahui dari item pertanyaan kuesioner no 1 yaitu: Dalam melaksanakan pekerjaannya pegawai bekerja secara efisien. Dari 20 responden, sebanyak $5(25,0 \%)$ orang menjawab kurang setuju dan $15(75,0 \%)$ orang menjawab sangat setuju. Hal ini menunjukkan bahwa pegawai dalam melaksanakan pekerjaannya bekerja cukup efisien, namun ada $25 \%$ pegawai yang menyatakan kurang setuju yang berarti $25 \%$ pegawai masih bekerja kurang efisien.

Tabel 4.6. Item Pertanyaan No. 3 


\begin{tabular}{|c|l|l|l|l|}
\hline & Frequency & Percent & $\begin{array}{c}\text { Valid } \\
\text { Percent }\end{array}$ & $\begin{array}{l}\text { Cumulative } \\
\text { Percent }\end{array}$ \\
\hline Valii 3 & 1 & 5.0 & 5.0 & 5.0 \\
4 & 13 & 65.0 & 65.0 & 70.0 \\
5 & 6 & 30.0 & 30.0 & 100.0 \\
Total & 20 & 100.0 & 100.0 & \\
\hline
\end{tabular}

Sumber: Distribusi Frekuensi Data

Berdasarkan Tabel 4.6. diketahui dari item pertanyaan kuesioner no 3 yaitu: Pegawai menggunakan peralatan kantor dengan sikap hati-hati. Dari 20 responden, sebanyak $1(6,0 \%)$ orang menjawab kurang setuju, $13(65,0 \%)$ orang menjawab setuju dan $6(30,0 \%)$ orang menjawab sangat setuju. Hal ini menunjukkan bahwa pegawai dalam menggunakan peralatan kantor sudah dengan sikap hati-hati.

Tabel 4.7. Item Pertanyaan No. 4

\begin{tabular}{|ll|r|r|r|r|}
\hline & & & & Cumulative \\
& & Frequency & Percent & Valid Percent & \multicolumn{1}{c|}{ Percent } \\
\hline Valid & 3 & 6 & 30.0 & 30.0 & 30.0 \\
& 4 & 14 & 70.0 & 70.0 & 100.0 \\
& Total & 20 & 100.0 & 100.0 & \\
\hline
\end{tabular}

Sumber: Distribusi Frekuensi Data

Berdasarkan Tabel 4.7. diketahui dari item pertanyaan kuesioner no 4 yaitu: Pegawai merawat peralatan kantor yang digunakannya dengan baik. Dari 20 responden, sebanyak $6(30,0 \%)$ orang menjawab kurang setuju dan $14(70,0 \%)$ orang menjawab setuju. Hal ini menunjukkan bahwa pegawai dalam merawat peralatan kantor yang digunakannya sudah cukup baik.

Tabel 4.8. Item Pertanyaan No. 5

\begin{tabular}{|c|c|c|c|c|c|}
\hline & & Frequency & Percent & Valid Percent & $\begin{array}{c}\text { Cumulative } \\
\text { Percent }\end{array}$ \\
\hline \multirow[t]{4}{*}{ Valid } & 3 & 5 & 25.0 & 25.0 & 25.0 \\
\hline & 4 & 13 & 65.0 & 65.0 & 90.0 \\
\hline & 5 & 2 & 10.0 & 10.0 & 100.0 \\
\hline & Total & 20 & 100.0 & 100.0 & \\
\hline
\end{tabular}

Sumber: Distribusi Frekuensi Data

Berdasarkan Tabel 4.8. diketahui dari item pertanyaan kuesioner no 5 yaitu: Pegawai senantiasa menyelesaikan tugas yang dibebankan sesuai dengan prosedur. Dari 20 responden, sebanyak $5(26,0 \%)$ orang menjawab kurang setuju, $13(65,0 \%)$ orang menjawab setuju dan $2(10,0 \%)$ orang menjawab sangat setuju. Hal ini menunjukkan bahwa pegawai dalam menyelesaikan tugas yang 
dibebankan sudah sesuai dengan prosedur, namun demikian masih ada $25 \%$ responden yang kurang mentaati prosedur.

Tabel 4.9. Item Pertanyaan No. 6

\begin{tabular}{|c|c|c|c|c|c|}
\hline & & Frequency & Percent & Valid Percent & $\begin{array}{l}\text { Cumulative } \\
\text { Percent }\end{array}$ \\
\hline \multirow[t]{3}{*}{ Valid } & 4 & 15 & 75.0 & 75.0 & 75.0 \\
\hline & 5 & 5 & 25.0 & 25.0 & 100.0 \\
\hline & Total & 20 & 100.0 & 100.0 & \\
\hline
\end{tabular}

Sumber: Distribusi Frekuensi Data

Berdasarkan Tabel 4.9. diketahui dari item pertanyaan kuesioner no 6 yaitu: Pegawai senantiasa menyelesaikan tugas yang dibebankan secara bertanggung jawab. Dari 20 responden, sebanyak 15 (75,0\%) orang menjawab setuju dan $5(25,0 \%)$ orang menjawab sangat setuju. Hal ini menunjukkan bahwa pegawai dalam menyelesaikan tugas yang dibebankan dilaksanakan dengan penuh tanggung jawab.

Tabel 4.10. Item Pertanyaan No. 7

\begin{tabular}{|r|r|r|r|r|}
\hline & & & & $\begin{array}{c}\text { Cumulative } \\
\text { Percent }\end{array}$ \\
\hline Valid & Frequency & Percent & Valid Percent & 45.0 \\
& 9 & 45.0 & 45.0 & 100.0 \\
& 11 & 55.0 & 55.0 & \\
\hline
\end{tabular}

Sumber: Distribusi Frekuensi Data

Berdasarkan Tabel 4.10. diketahui dari item pertanyaan kuesioner no 7 yaitu: Pegawai dalam melaksanakan tugasnya menggunakan atribut kantor yang telah ditentukan. Dari 20 responden, sebanyak 9 (45,0\%) orang menjawab kurang setuju dan $11(65,0 \%)$ orang menjawab setuju. Hal ini menunjukkan bahwa pegawai dalam melaksanakan tugasnya sebagian masih kurang taat menggunakan atribut kantor yang telah ditentukan, hal ini terjadi kemungkinan karena mereka adalah pegawai yang lebih banyak di lapangan.

Tabel 4.11. Item Pertanyaan No. 8

\begin{tabular}{|rl|r|r|r|r|}
\hline & & & & \multicolumn{2}{c|}{$\begin{array}{c}\text { Cumulative } \\
\text { Percent }\end{array}$} \\
\hline Valid & Frequency & Percent & Valid Percent & 55.0 \\
& 11 & 55.0 & 55.0 & 100.0 \\
& 9 & 45.0 & 45.0 & \\
& Total & 20 & 100.0 & 100.0 & \\
\hline
\end{tabular}

Sumber: Distribusi Frekuensi Data

Berdasarkan Tabel 4.11. diketahui dari item pertanyaan kuesioner no 8 yaitu: Pegawai membuat ijin apabila tidak masuk kerja. Dari 20 responden, sebanyak $11(55,0 \%)$ orang menjawab setuju dan $9(45,0 \%)$ orang menjawab sangat setuju. Hal ini menunjukkan bahwa pegawai senantiasa membuat ijin apabila tidak masuk kerja.Secara keseluruhan kondisi variabel disiplin kerja (X) diketahui sebagai berikut:

Skor maksimal/ideal :800, skor riil : 645 


$$
: \underline{645} \times 100=80,63 \%
$$

800

Berdasarkan hasil perhitungan diatas didapatkan hasil 83,41\% yang berarti variabel disiplin kerja termasuk kategori baik.

Tabel 4.14. Item Pertanyaan No. 11

\begin{tabular}{|rl|r|r|r|r|}
\hline & & & & Cumulative \\
& Frequency & Percent & Valid Percent & \multicolumn{2}{|c|}{ Percent } \\
\hline Valid 4 & 14 & 70.0 & 70.0 & 70.0 \\
& 6 & 30.0 & 30.0 & 100.0 \\
& Total & 20 & 100.0 & 100.0 & \\
\hline
\end{tabular}

Sumber: Distribusi Frekuensi Data

Berdasarkan Tabel 4.14. diketahui dari item pertanyaan kuesioner no 11 yaitu: Pegawai bersedia bekerja sama dengan pegawai lain untuk mencapai tujuan organisasi. Dari 20 responden, sebanyak 14 (70,0\%) orang menjawab setuju dan 6 $(30,0 \%)$ orang menjawab sangat setuju. Hal ini menunjukkan bahwa pegawai bersedia bekerja sama dengan pegawai lain untuk mencapai tujuan organisasi.

Tabel 4.15. Item Pertanyaan No. 12

\begin{tabular}{|c|c|c|c|c|c|}
\hline & & Frequency & Percent & Valid Percent & $\begin{array}{c}\text { Cumulative } \\
\text { Percent }\end{array}$ \\
\hline \multirow[t]{3}{*}{ Valid } & 4 & 13 & 65.0 & 65.0 & 65.0 \\
\hline & 5 & 7 & 35.0 & 35.0 & 100.0 \\
\hline & Total & 20 & 100.0 & 100.0 & \\
\hline
\end{tabular}

Sumber: Distribusi Frekuensi Data

Berdasarkan Tabel 4.15. diketahui dari item pertanyaan kuesioner no 12 yaitu: Pegawai bersedia membantu dan memberikan informasi yang diperlukan pegawai lain untuk menyelesaikan pekerjaan. Dari 20 responden, sebanyak 13 $(65,0 \%)$ orang menjawab setuju dan $7(35,0 \%)$ orang menjawab sangat setuju. Hal ini menunjukkan bahwa pegawai bersedia saling membantu dan memberikan informasi yang diperlukan pegawai lain untuk menyelesaikan pekerjaan.

Tabel 4.16. Item Pertanyaan No. 13

\begin{tabular}{|c|c|c|c|c|c|}
\hline & & Frequency & Percent & Valid Percent & $\begin{array}{c}\text { Cumulative } \\
\text { Percent }\end{array}$ \\
\hline \multirow[t]{3}{*}{ Valid } & 4 & 9 & 45.0 & 45.0 & 45.0 \\
\hline & 5 & 11 & 55.0 & 55.0 & 100.0 \\
\hline & Total & 20 & 100.0 & 100.0 & \\
\hline
\end{tabular}

Sumber: Distribusi Frekuensi Data

Berdasarkan Tabel 4.16. diketahui dari item pertanyaan kuesioner no 13 yaitu: Pegawai saling menjalin komunikasi satu sama lain dalam menjalankan pekerjaannya. Dari 20 responden, sebanyak $9(45,0 \%)$ orang menjawab setuju dan $11(55,0 \%)$ orang menjawab sangat setuju. Hal ini menunjukkan bahwa pegawai bersedia saling menjalin komunikasi satu sama lain dalam menjalankan pekerjaannya.

Tabel 4.17. Item Pertanyaan No. 14 


\begin{tabular}{|ll|r|r|r|r|}
\hline & Frequency & Percent & Valid Percent & $\begin{array}{c}\text { Cumulative } \\
\text { Percent }\end{array}$ \\
\hline Valid & 3 & 7 & 35.0 & 35.0 & 35.0 \\
& 4 & 13 & 65.0 & 65.0 & 100.0 \\
& Total & 20 & 100.0 & 100.0 & \\
\hline
\end{tabular}

Sumber: Distribusi Frekuensi Data

Berdasarkan Tabel 4.17. diketahui dari item pertanyaan kuesioner no 14 yaitu: Pegawai bersedia membantu kesulitan rekan kerjanya untuk menyelesaikan masalah pekerjaan yang dihadapinya. Dari 20 responden, sebanyak $7(35,0 \%)$ orang menjawab kurang setuju dan $13(65,0 \%)$ orang menjawab setuju. Hal ini menunjukkan bahwa pegawai bersedia membantu kesulitan rekan kerjanya untuk menyelesaikan masalah pekerjaan yang dihadapinya, namun demikian masih ada sebagian pegawai yang kurang mau membantu kesulitan pekerjaan rekannya sebnyak $35 \%$.

Tabel 4.18. Item Pertanyaan No. 15

\begin{tabular}{|rl|r|r|r|r|}
\hline & & & & \multicolumn{2}{c|}{$\begin{array}{c}\text { Cumulative } \\
\text { Percent }\end{array}$} \\
\hline Valid 3 & Frequency & Percent & Valid Percent & 50.0 \\
& 10 & 50.0 & 50.0 & 100.0 \\
& 10 & 50.0 & 50.0 & \\
& Total & 20 & 100.0 & 100.0 & \\
\hline
\end{tabular}

Sumber: Distribusi Frekuensi Data

Berdasarkan Tabel 4.18. diketahui dari item pertanyaan kuesioner no 15 yaitu: Pegawai mampu menyelesaikan pekerjaannya sesuai dengan target yang telah ditetapkan. Dari 20 responden, sebanyak $10(50,0 \%)$ orang menjawab kurang setuju dan $10(50,0 \%)$ orang menjawab setuju. Hal ini menunjukkan bahwa separuh pegawai lapangan mampu menyelesaikan pekerjaannya sesuai dengan target yang telah ditetapkan, sedangkan separuhnya lagi kurang bisa memenuhi target pekerjaannya.

Tabel 4.19. Item Pertanyaan No. 16

\begin{tabular}{|ll|r|r|r|r|}
\hline & & & & Cumulative \\
& & Frequency & Percent & Valid Percent & Percent \\
\hline Valid & 9 & 45.0 & 45.0 & 45.0 \\
& 9 & 45.0 & 45.0 & 90.0 \\
& 2 & 10.0 & 10.0 & 100.0 \\
& & 20 & 100.0 & 100.0 & \\
\hline
\end{tabular}

Sumber: Distribusi Frekuensi Data

Berdasarkan Tabel 4.19. diketahui dari item pertanyaan kuesioner no 16 yaitu: Pegawai mampu menyelesaikan pekerjaan yang ekstra dengan cepat. Dari 20 responden, sebanyak $9(45,0 \%)$ orang menjawab kurang setuju, $9(45,0 \%)$ orang menjawab setuju dan $2(10,0 \%)$ orang menjawab sangat setuju. Hal ini menunjukkan bahwa sebagian besar pegawai mampu menyelesaikan pekerjaan yang ekstra dengan cepat, tetapi masih ada $45 \%$ pegawai yang kurang bisa menyelesaikan pekerjaan ekstranya dengan cepat.

Tabel 4.20. Item Pertanyaan No. 17 


\begin{tabular}{|rl|r|r|r|r|}
\hline & & & & \multicolumn{2}{|c|}{$\begin{array}{c}\text { Cumulative } \\
\text { Percent }\end{array}$} \\
\hline Valid & Frequency & Percent & Valid Percent & 15.0 \\
& 3 & 15.0 & 15.0 & 60.0 \\
& 9 & 45.0 & 45.0 & 100.0 \\
& & 8 & 40.0 & 40.0 & \\
& Total & 20 & 100.0 & 100.0 & \\
\hline
\end{tabular}

Sumber: Distribusi Frekuensi Data

Berdasarkan Tabel 4.20. diketahui dari item pertanyaan kuesioner no 17 yaitu: Pegawai mampu mencari alternatif solusi dalam menyelesaikan pekerjaannya. Dari 20 responden, sebanyak $3(15,0 \%)$ orang menjawab kurang setuju, $9(45,0 \%)$ orang menjawab setuju dan $8(40,0 \%)$ orang menjawab sangat setuju. Hal ini menunjukkan bahwa sebagian besar pegawai mampu mencari alternatif solusi dalam menyelesaikan pekerjaannya, hanya $15 \%$ pegawai saja yang kurang mampu mencari alternatif solusi. Secara keseluruhan kondisi variabel kinerja pegawai (Y) diketahui sebagai berikut:

Skor maksimal/ideal :900, skor riil : 720

$$
: \underline{720} \times 100=80 \%
$$

900

Berdasarkan hasil perhitungan diatas didapatkan hasil $80 \%$ yang berarti variabel kinerja pegawai termasuk kategori baik.

\section{Analisis Korelasi}

Mengetahui hubungan variabel bebas terhadap variabel terikat juga sekaligus mengetahui pengaruh diantara dua variabel tersebut.

\section{Analisis Korelasi Rank Spearman}

Analisis korelasi berusaha mengukur eratnya hubungan antara dua variabel independen $(\mathrm{X})$ dengan vaiabel dependen $(\mathrm{Y})$ dengan menggunakan suatu bilangan yang disebut koefisien korelasi (r).

Berdasarkan hasil olah data dengan SPSS diketahui:

Tabel.4.21 Hasil Uji Korelasi Rank Spearman

\section{Correlations}

\begin{tabular}{|c|c|c|c|c|}
\hline & & & Var_X & Var_Y \\
\hline \multirow[t]{6}{*}{ Spearman's rho } & \multirow[t]{3}{*}{ Var_X } & $\begin{array}{l}\text { Correlation } \\
\text { Coefficient }\end{array}$ & 1.000 & $.833^{\text {** }}$ \\
\hline & & Sig. (2-tailed) & & .000 \\
\hline & & $\mathrm{N}$ & 20 & 20 \\
\hline & \multirow[t]{3}{*}{ Var_Y } & $\begin{array}{l}\text { Correlation } \\
\text { Coefficient }\end{array}$ & $.833^{* *}$ & \multirow[t]{3}{*}{1.000} \\
\hline & & Sig. (2-tailed) & .000 & \\
\hline & & $\mathrm{N}$ & 20 & \\
\hline
\end{tabular}

${ }^{* \star}$. Correlation is significant at the 0.01 level (2-tailed).

Sumber : Data Diolah dari Uji Korelasi 
Hasil Output SPSS menunjukkan bahwa dengan sig. atau $\mathrm{p}=0,000$ maka untuk mengetahui hasilnya adalah $\mathrm{rxy}=0,833 ; \mathrm{p}=0,000$ adalah $\mathrm{p}<0,05$ maka "terdapat hubungan yang positif dan signifikan antara varibel $\mathrm{X}$ dengan $\mathrm{Y}$ dengan taraf signifikansi $5 \%$ pada derajat hubungan yang sangat erat.

\section{Analisis Koefisien Determinasi $\left(\mathbf{r}^{2}\right)$}

Koefisien determinasi adalah untuk menentukan seberapa besar variasi variabel dependen (Y) yang dapat dijelaskan oleh variabel independen (X).

Tabel 4.22 Tabel Model Summary

\begin{tabular}{|l|r|r|r|r|}
\multicolumn{6}{|c|}{ Model Summary } \\
\hline Model & $\mathrm{R}$ & \multicolumn{1}{c|}{ R Square } & Adjusted R Square & \multicolumn{1}{c|}{$\begin{array}{c}\text { Std. Error of the } \\
\text { Estimate }\end{array}$} \\
\hline 1 & $.826^{\mathrm{a}}$ & .682 & .664 & 1.31611 \\
\hline
\end{tabular}

a. Predictors: (Constant), Var_X

Interpretasi: nilai $r=0.826$ maka $r^{2}=0,682$ ini berarti bahwa variabel kinerja pegawai (Y) dapat dijelaskan oleh variabel didiplin kerja (X) sebesar 68,2\%. Sedangkan sisanya sebesar 21,8\% dijelaskan oleh faktor lain diluar penelitian ini.

\section{Permasalahan Disiplin Kerja dan Kinerja Pegawai}

Berdasarkan observasi yang peneliti lakukan di luar data kuesioner diketahui beberapa permasalahan yang menghambat disiplin kerja dankinerja pegawai di PT WOM Finance Kebumen, antara lain:

\section{A. Disiplin Kerja (X)}

1. Masih terdapat $25 \%$ pegawai lapangan yang kurang mentaati prosedur perusahaan.

2. Masih terdapat $45 \%$ pegawai lapangan yang kurang taat menggunakan atribut perusahaan yang telah ditentukan.

\section{B. Kinerja Pegawai (Y)}

1. Masih terdapat $25 \%$ pegawai lapangan yang dalam melaksanakan tugasnya kurang teliti dan tepat.

2. Masih terdapat $20 \%$ pegawai lapangan yang kurang rapih dan bersih dalam menyelesaikan tugas-tugasnya.

3. Masih ada sebagian pegawai lapangan yang kurang mau membantu kesulitan pekerjaan rekannya sebanyak $35 \%$.

4. Masih terdapat $45 \%$ pegawai lapangan yang kurang bisa menyelesaikan pekerjaan ekstranya dengan cepat.

\section{Upaya-Upaya Mengatasi Masalah}

Permasalahan-permasalahan di atas dapat diatasi dengan cara, antara lain:

\section{Disiplin Kerja (X)}

1. Terhadap pegawai lapangan yang kurang mentaati prosedur perusahaan perlu diberi pembinaan, pengawasan, teguran, sampai pada pemberian sanksi.

2. Terhadap pegawai lapangan yang kurang taat menggunakan atribut perusahaan yang telah ditentukan perlu diberi pembinaan, pengawasan, teguran, sampai pada pemberian sanksi.

\section{Kinerja Pegawai (Y)}

3. Terhadap pegawai lapangan yang dalam melaksanakan tugasnya kurang teliti dan tepat, perlu iberikan tambahan pendidikan dan pelatihan, dan apabila tidak ada perubahan positif maka pemberian teguran, sampai pada pemberian sanksi patut diberikan. 
4. Terhadap pegawai lapangan yang kurang rapih dan bersih dalam menyelesaikan tugastugasnya, perlu diberikan pembinaan sampai pada pemberian sanksi..

5. Terhadap pegawai lapangan yang kurang mau membantu kesulitan pekerjaan rekannya dalam menyelesaikan pekerjaan, perlu diberi pemahaman mengenai pentingnya bekerja sebagai team work dalam mencapai tujuan perusahaan.

6. Terhadap pegawai lapangan yang kurang bisa menyelesaikan pekerjaan ekstranya dengan cepat, perlu diberikan tambahan pelatihan dan pemberian bonus sehingga pegawai lebih termpil dan termotivasi.

\section{KESIMPULAN}

Berdasarkan hasil penelitian yang dilakukan pada PT WOM Finance Kebumen, maka kesimpulan yang dapat dikemukakan dalam penelitian ini adalah sebagai berikut :

1. Disiplin kerja pegawai pada PT WOM Finance Kebumen berdasarkan hasil perhitungananalisis deskriptif didapatkan hasil $83,41 \%$ yang berarti variabel disiplin kerja termasuk kategori baik..

2. Kinerja pegawai pada PT WOM Finance Kebumen berdasarkan hasil perhitungananalisis deskriptif didapatkan hasil $80 \%$ yang berarti variabel kinerja pegawai termasuk kategori baik..

3. Terdapat hubungan yang positif dan signifikan antara varibel $\mathrm{X}$ dengan $\mathrm{Y}$ pada taraf signifikansi 5\% pada derajat hubungan yang sangat erat.pada PT WOM Finance Kebumen. Berdasarkan hasil uji koefisien determinasi didapat nilai $\mathrm{r}^{2}=0,682$ ini berarti bahwa variabel kinerja pegawai (Y) dapat dijelaskan oleh variabel didiplin kerja (X) sebesar 68,2 $\%$. Sedangkan sisanya sebesar 21,8\% dijelaskan oleh faktor lain diluar penelitian ini.

4. Permasalahan pada disiplin kerja dan kinerja pegawai pada PT WOM Finance Kebumen antara lain: masih terdapat pegawai lapangan yang kurang mentaati prosedur perusahaan, kurang taat menggunakan atribut perusahaan, melaksanakan tugasnya kurang teliti dan tepat, kurang rapi dan bersih dalam menyelesaikan tugas-tugasnya, kurang mau membantu kesulitan pekerjaan rekannya, dan kurang bisa menyelesaikan pekerjaan ekstranya dengan cepat.

5. Upaya pemecahan masalahnya pada disiplin kerja dan kinerja pegawai pada PT WOM Finance Kebumen antara lain pemberian tambahan pendidikan dan pelatihan, pemberian pemahaman pentingnya bekerja sebagai tim, bonus untuk pekerjaan ekstra sehingga pegawai lebih termotivasi, pemberian pembinaan, pengawasan, teguran, sampai pada pemberian sanksi khusunya.

\section{E. DAFTAR PUSTAKA}

Achmadi, Abu dan Cholid Narbuko. 2009. Metodologi Penelitian. Bumi Aksara. Jakata.

Erna dan Muhktar Widodo. 2001. Konstruksi ke Arah Penelitian Deskriptif. Ayyrruz.Yogyakarta.

Handoko TH,. 2001. Manajemen Personalia dan Sumber Daya Manusia. Edisi 2. BPFE. Yogyakarta.

Hasibuan, Malayu. 2001. Manajemen Sumber Daya Manusia: Pengertian Dasar, Pengertian, dan Masalah. Gunung Agung. Jakarta.

Mangkunegara, Anwar Prabu. Manajemen Sumber Daya Manusia Perusahaan. PT. Remaja Rosdakarya. Bandung.

Narbuko, Cholid dan Abu Achmadi. 2012. Metodologi Penelitian. Bumi Aksara. Jakarta.

Ranupandojo, H. \& Suad, H. 2000. Manajemen Personalia. Yogyakarta: BPFE. 
Rivai, Veithzal. 2005. Manajemen Sumber Daya Manusia untuk Perusahaan dari Teori ke Praktik. Cetakan Pertama, Februari 2005. Jakarta : Penerbit PT. Raja Grafindo Persada.

Sastrohadiwiryo, B, Siswanto, 2003. Manajemen Tenaga Kerja Indonesia.Edisi 2. Bumi Aksara.Jakarta.

Sugiyono. 2009. Metode Penelitian Bisnis (Pendekatan Kuantitatif, Kualitatif, dan R\&D). Alfabeta. Bandung. 